\title{
BRINGING THE POLITICS BACK IN: PUBLIC VALUE IN WESTMINSTER PARLIAMENTARY GOVERNMENT
}

\author{
R.A.W. RHODES AND JOHN WANNA
}

We challenge the usefulness of the 'public value' approach in Westminster systems with their dominant hierarchies of control, strong roles for ministers, and tight authorizing regimes underpinned by disciplined two-party systems. We identify two key confusions: about public value as theory, and in defining who are 'public managers'. We identify five linked core assumptions in public value: the benign view of large-scale organizations; the primacy of management; the relevance of private sector experience; the downgrading of party politics; and public servants as platonic guardians. We identify two key dilemmas around the 'primacy of party politics' and the notion that public managers should play the role of platonic guardians deciding the public interest. We illustrate our argument with short case studies of: the David Kelly story from the UK; the 'children overboard' scandal in Australia; the 'mad cow disease' outbreak in the UK; the Yorkshire health authority's 'tea-parties', and the Cave Creek disaster in New Zealand.

\section{INTRODUCTION}

Stimulated by the seminal work of Mark Moore (1995), the 'public value' approach encouraged a more positive view of the public sector. It supported publicly minded officials keen to make a difference. It also provoked a conversation about the 'service ethic' and implementation for improving the quality of public provision. Following the political ascendancy of the neo-liberal ideological agenda in the West that lambasted 'state failure' and unresponsive bureaucracies, public value revitalized the vocation of the public administrator in Westminster systems, giving public officials something to believe in again. As a result, it attracted many disciples, proselytisers and camp followers (see, for example, Kelly et al. 2002; Alford 2008; Benington and Moore 2010). But public value is not just some academic paradigm or intellectual fad; it has been taken up readily in a number of Westminster systems and has been endorsed by many senior public servants, especially in Australia, New Zealand and the United Kingdom.

We believe that a critical engagement with the idea of public value will sharpen the debate and make the theory of public value more robust. We explore the assumptions behind the public value approach and criticize their relevance as 'a structure of practical reasoning to guide managers of public enterprises' (Moore 1995, p. 1, emphasis added) in Westminster systems of parliamentary government such as Australia, Britain, Canada and New Zealand. While we restrict our analysis here to these countries, many of our criticisms would apply to other forms of parliamentary government with different traditions of governance. We focus on Moore's Creating Public Value (1995) since the arguments have changed but little (see Moore 1994 and 2007). We argue it mistakenly diagnoses the roles of management in the modern public sector. It invents roles for public servants for which they are not appointed, are ill-suited, inadequately prepared and, more importantly, not protected if things go wrong. It asks public managers to

R.A.W. Rhodes holds a joint appointment as Professor of Government in the School of Government at the University of Tasmania and Distinguished Professor of Political Science in the Research School of Social Sciences at the Australian National University. John Wanna is the inaugural Sir John Bunting Chair of Public Administration at the Research School of Social Sciences at the Australian National University and Director of Research for the Australian and New Zealand School of Government (ANZSOG). 
supplant politicians, to become engaged in the political process, and become the new platonic guardians and arbiters of the public interest. We provide illustrative cases to highlight these misunderstandings of the crucial relations between ministers as elected and accountable politicians and their unelected public officials.

\section{CONFUSIONS}

We identify two key confusions: about public value as theory; and in defining public managers. We identify five linked core assumptions in public value: the benign view of large-scale organizations; the primacy of the management function; the relevance of private sector experience; downgrading the primacy of party politics; and public servants cast in the role of platonic guardians.

\section{Public value as theory}

To evaluate any approach we need to know what the author claims for it. Is it a new empirical theory? Is a set of techniques for managers? It is unclear whether Moore offers a new theoretical framework, a concept, a heuristic device, or an operational tool of management. He shifts between these meanings depending on the argument or case. He claims to present a normative theory of managerial behaviour that will 'lay out a structure of practical reasoning to guide managers of public enterprises' with the aim of telling managers what they 'should think and do' (Moore 1995: 1-2, original emphasis). Yet, he slides in seamless progression from operational improvements at the workplace to higher levels where public value is an aspiration for the governmental system. He combines empirical evidence (usually drawn from illustrative cases of bottom-up innovation) with normative notions for reforming public organizations that will produce better public policy and augment the public interest in unambiguous ways. All too often it is unclear whether Moore is developing a normative argument or an empirical-operational one. It matters. The criteria for evaluating ideals differ from those that seek to assess evidence.

\section{Defining 'public managers'}

Moore stretches the definition of the 'public manager' way beyond its conventional meaning in Westminster systems. While he principally addresses his message to managers of public enterprises, he includes the following: elected, unelected and self-appointed actors including politicians, 'presidents, governors and mayors', political and 'policy staff', 'administrators, commissioners and directors', 'senior civil servants', experts with 'deep substantive knowledge', 'staffs on key legislative oversight committees', 'judges', lobbyists and 'those who lead interest groups', and even 'private sector managers' if they produce mainly for the government (Moore 1995, pp. 2-3). The cast is inclusive and expansive and a source of potential confusion when applied to Westminster systems. In sharp contrast to the US, officials in Westminster systems, and in most parliamentary systems more generally, are rarely if ever elected. Indeed, there is also no analogy to presidential appointees. The political appointment of public officials is the exception not the rule in Australia, Britain and New Zealand. So, the elected politicians have a legitimate role in deciding what is in the public interest under the conventional norms of representative democracy, but non-elected officials do not share that role. There is a widely shared understanding that the roles of elected politician and appointed official are sharply demarcated. Each has distinctive rights, responsibilities and bases of legitimacy. So, we need a theory that encompasses that separateness. Yet, despite his 
all-encompassing definition, most of Moore's real-life examples talk to, and focus on, the unelected individual public manager, not the elected and formally accountable politicians.

\section{ASSUMPTIONS}

\section{Benign organizations}

Public value assumes a commonweal view of politics and governance. Actors such as governments, public organizations and interest groups are assumed to want to do good things. They are motivated only to assist and please citizens; to create public value and improve the public good. There is, thus, and paradoxically for an American scholar, a benign view of all public and private large-scale organizations. Actors in these contexts are considered to be interested in the well-being of others, not exploitative, cabalistic or mainly self-interested. Yet, public organizations do not exist solely to perform pleasant tasks. Many exist to enforce state rules, to push people into work, to achieve targets at the lowest cost, or to ration public goods and services.

Power imbalances both in the bureaucratic chain of command and between state officials and clients, citizens or interest groups are assumed away or played down. Power rarely figures in the explanations or the cases. Often there is an assumption public value produces win-win situations. So, if all the actors are indispensable to achieving a successful outcome, and all have their own power resources, then they all share the incentive to make trade-offs to achieve the collective aims. This stance ignores the asymmetrical power structures between state officials, groups, and individual clients or citizens.

In addition, the emphasis falls on benign features of managerial action. We hear of displays of public-minded commitment or of successful innovation. Moore tells stories about managers developing new skills and capacity or initiating collaborations, and about individual enthusiasm and courage. Other managerial tasks such as control, direction, constraint management, rationing, sanctioning or enforcing penalties are conspicuous mainly for their absence. In short, the dark side of the state and its administrative arms is largely ignored in the 'public value' vision.

\section{The primacy of management}

Public value approaches take for granted the primacy of management in government organizations. Public value is the successor and heir apparent to New Public Management and suffers from the same weaknesses inherent in such managerialist approaches. Management is seen through the eyes of the individual manager who works within a strategy that is goal-oriented, legitimate and feasible - the strategic triangle. Agency and individual choices are stressed over structures and organizations. Individual managers, not organizations, devise and make strategies to 'gain virtue' (according to some measure of improvement or satisfaction) even if they rely on other people to make them work. In Stoker's words (2005, p. 55), this conception pushes managers into 'doing politics'. Moore (1995, Chs 4 and 5) repeatedly points out that managers must exercise 'policy management' or 'political management' within the constraints of their 'authorizing environment' to 'fashion legitimacy and support for themselves, their policies, or their organisational strategies' (Moore 1995, pp. 12, 23, 113 and 169ff). His view of the manager presupposes an institutional environment in which managers exercise a degree of autonomy and initiative and even entrepreneurialism that is not typical of public servants in Westminster systems or welcomed by their political masters.

As 'entrepreneurs' and 'entrepreneurial advocates' (Moore 1995, p. 151), the onus is then placed on these managers to define or find the areas where public value can be created. 
They are responsible for identifying potential opportunities to create public value. The role of the public manager is to act as a 'public explorer', a 'discoverer', an 'entrepreneurial advocate', a 'creator', and a 'steerer' rather than the 'rower' or functionary in government agencies (Moore 1995, Ch. 5 and Conclusion). In doing so, they are shaping the operational definition of the public interest and largely determining whether the state ought, or is motivated, to invest in such value. They are playing small ' $p$ ' bureaucratic politics as they 'become strategists'. In Moore's (1995, p. 20) words: 'they engage the politics surrounding their organization to help define public value as well as engineer how their organizations operate'. He does not apparently care whether they are equipped or prepared to cope with the risks. He does not care whether they could subvert or undermine their core business or main areas of responsibility. It may be a nice idea, to use Moore's first example, for a librarian to offer street kids a place of sanctuary and care, but one might ask why is a library with its vast resources of knowledge being converted into a childcare centre and soup kitchen.

Although other actors may subsequently become involved (when managerial initiatives float 'up the bureaucratic chain' to the authorizing regime, p. 151), public officials initiate attempts to create public value. Thus, 'society needs value-seeking imaginations (and associated technical skills) from its public sector executives no less than from its private sector managers' (Moore 1995, p. 21). Public managers become internal lobbyists for particular valued strategies, and by providing 'more formal channels through which managerial ideas about opportunities to create public value could be properly expressed' they become less 'vulnerable to self-interest'. He continues: 'it would also be important to teach public managers how to search for and define public value more properly and effectively than they do now', to 'allow society to have the benefit of the experience and imagination of public sector managers without having to yield to their particular conceptions of the public interest' (Moore 1995, p. 21). Yet, these managers are still the principal formulators of notions of public value.

In his illustrative cases, Moore is careful to avoid his managers confronting large ' $\mathrm{P}$ ' politics, moral dilemmas, or major value conflicts. He chooses real-life examples that highlight the ordinary and mundane areas of public policy and policy implementation, such as public libraries, refuse collection, correctional services and environmental management. Who can object to latchkey kids being cared for by a sympathetic librarian or a sanitation commissioner devising new ways to help citizens keep cities clean? In such low risk examples, the notion of public value is less controversial because we can identify some societal consensus about what constitutes the 'social benefit' (for a discussion of the 'public value ladder' on degrees of political risk, see Rhodes and Wanna 2007). So, public value appears to have generic application. However, such agreement often does not exist.

Moore's choice of policies that create public value focus on benign service provision where an agreed 'good' can be produced and the relevant stakeholders approve. In the American context, this emphasis on societal approval is all too easy to understand given its anti-statist tradition and long-standing backdrop of hostility to government intervention. American citizens tend to believe public officials are self-interested. So it is important for the managerialist Moore to counter this view by identifying interventions that command agreement. We do not find adherents of the public value approach making cases for widening the net of tax collection or making it more rapacious, hospital managers selling human organs to meet demand, better wheel clamping of parking offenders, quicker and more available abortions whenever a woman desires, incentive payments to police to catch more speeding motorists, or bounty-hunting for escaped criminals. The assumption 
is that a consensus can be identified or engineered by managers that will express the public good. It is not clear how entrepreneurial officials are to exercise their own moral compass in creating public value where there is conflict. It is not clear what role party politics will play in managing that conflict and identifying policies. It is not clear how public officials work with the political parties (if at all) or how they will contribute to their policy processes.

\section{Learning from the private sector}

Rather curiously, Moore's response to conflict, and we suspect it is a business school perspective, is not to turn to an examination of the political process but to best practice business techniques and role modelling taken from private sector experience. He advises public officials seeking to create public value to copy the private sector and behave like corporate executives. He argues the public sector should adopt successful private sector approaches to corporate strategy to identify and create public value. His argument presupposes, on the one hand, that there are few significant differences between the public and private sectors, or that 'constitutional' differences can be overcome with appropriate leadership and corporate strategic planning. On the other hand, his argument presupposes the virtues of planning and evidence-based processes, in short, the desirability of the rational actor model of decision making by corporate leadership. So, he advances the argument that:

a high-quality decision is one that has a large measure of both process and substantive virtues. A decision acquires process virtues by emerging from a wide consultation process in which all interested parties have had a chance to be consulted, and all the formal legal rules governing the process of decision-making have been met. A decision acquires substantive legitimacy to the extent that the decision has been able to draw into the policy-making process as many relevant facts as are available, arrayed in an analytic framework that accurately represents the important values at stake in the decision, the principal alternatives open to decision-makers, and the likely consequences of the alternative choices (reckoned in dimensions of significance to the decision-makers). (Moore 1995, pp. 163-4; original emphasis)

We are sceptical of these arguments. First, on the public-private distinction, Moore (1995, p. 64) argues it is 'easy to exaggerate the significance of these differences' between the roles of private and public executives (Moore 1995, p. 64). He cites Allison (1983) on the distinctiveness of the public sector but ignores the significance of these differences for public enterprise managers (see Moore 1995, pp. 343-4, endnote 25; and 356, endnote 3). There is a considerable international literature that explores the substantive differences between public and private arenas (see Ranson and Stewart 1989; Rainey and Chun 2005). Moore downplays their significance.

Second, if private sector techniques offer such obvious and available ways to manage, then why is so little implemented across government? It is not because public managers are ill-trained, stupid or venal, but because private sector techniques do not fit the context, can be neutered by both bureaucratic and political games, and are not subjected to the same accountability as public management. In addition, public sector officials do not share the same risks and rewards.

Third, the rational comprehensive model of policy-making is an idealized notion largely removed from the reality of public policy-making. Politics, value clashes, interests, cultures, symbolic imperatives, processes, and accountability requirements all make the 
rational actor model untenable in public policy decision making. These limits have been spelt out so often, they need no repetition here (see, for example, Wildavsky 1979; Lindblom 1990).

\section{Downgrading party politics}

Politics is portrayed as a 'problem' in public value accounts, almost as an illegitimate interference standing in the way of good management. It prevents managers from 'exercising much imagination about the proper purposes of government' or developing interests in new ideas or improving the delivery chain (Moore 1995, p. 21). Tales abound about the practical difficulties of doing anything because 'politics' gets in the way or exercises a veto, or because it is hard to attract attention higher up, or because it is difficult to get politicians to focus on the micro-politics of production. The solution is to transfer real political responsibility to front-line officials, and have them negotiate approval for their proposed actions.

For anyone in Australasia, Canada or Britain reading Moore on politics, it is obvious he is talking about the American system of government and its pluralistic politics. There is nary a mention of either party politics or the constitutional conventions of ministerial and collective responsibility. Political parties do not figure significantly in his conception of politics, either as mobilizers of mass support or collectivities of ideas, policies and ideologies. Nowhere does the word Republican or Democrat appear in the policy process. Occasionally 'legislators' or 'representatives' appear but only as final gatekeepers or overseers. It would be inconceivable in Westminster systems to write a book on politics and policy-making without mentioning the respective parties (Conservative, Labour, Liberal, National, Labor) given that they bring most of the political initiative to government.

There is also no discussion of the constitutional bureaucracy - the 'permanent' part of the state composed of career public servants who provide ongoing advice, play devil's advocate to the pleadings of sectional interests, keep an eye on due process, preserve the collective memory, and consider long-term public interests even when government is preoccupied with other pressing issues (see Parris 1969; Rhodes et al. 2008). The American term 'neutral competence', meaning administrative specialists who can serve different administrations or broker between separated institutions such as congress and the president, does not encompass Westminster roles.

There may be no agreed definition of Westminster or even parliamentary government, but most versions embrace the ideas of centralization and hierarchy. For example Strøm and his colleagues (2003, Chs 3 and 23) see parliamentary democracy as a chain of delegation from principals to agents, from voters to their elected representatives, from legislators to the chief executive, from the chief executive to ministerial heads of departments, and from ministers to civil servants. Gamble's (1990, p. 407) definition encompasses a unitary state; parliamentary sovereignty; strong cabinet government; and majority party control of the executive (that is, prime minister, cabinet and the civil service). Moore (and his several followers) provides no assessment of the impact of a clear political and administrative hierarchy for the practices of creating public value. To be fair to Moore, he is often the victim of his followers' enthusiasm. We can find only one point where he discusses the applicability of his ideas in other governmental systems (Moore 1995, pp. 4, 313, endnote 16). His error is to believe his supporters. That conceded, clearly, ideas such as hierarchy; strong cabinet government and majority party control of the executive; ministerial control of officials and merit appointment of neutral officials; 
fit ill with the public value approach. Whatever Moore's public value may be about, it is never about majority party centralization and control.

\section{Public officials as platonic guardians}

The inherent danger with 'public value management' is that public managers are asked to serve as the platonic guardians and arbiters of the public interest. They are charged with imagining value and defending their notions of the 'public good' against other conceptions. So, although public value writers often stress the importance of collective preferences and participatory involvement of the community, public value approaches are premised on a fundamentally non-democratic notion. Bureaucracy and bureaucratic interests predominate and displace democratic preferences.

In three revealing sentences Moore gives the game away. His public value managers, he admits,

will search covertly for ways to express their real values. Instead of trying to accommodate conflicting claims in new syntheses, they will decide instead to anchor their preferred vision of their purposes with that portion of their (divided) authorizing environment that agrees with them. Thus, the secret image of virtue among government managers becomes one of skilled advocates building powerful dikes protecting themselves, their organizations, and their causes from the political tides that sweep over the more gullible, dutiful bureaucrats. (1995, p. 299)

A more unabashed platonic doctrine would be hard to find. The virtuous apparently know best.

In public value management, there is no discernable difference between public value and the public interest. They are interchangeable. If public managers are benign, as Moore believes, then they can interpolate public preferences and advance the public interest by initiating improvements in delivery to mutual advantage. Value adding is a one-way process - organizations can keep on doing what they do or add value through innovation. But who says it is of 'value', and what if innovations lead to deteriorations in delivery? Moore insists the 'public' or community, or more narrowly the 'stakeholders', are somehow the arbiters of 'value'. But because he distrusts the formal electoral process (Moore 1995, pp. 52-6), managers have to turn to other surrogate measures of support. They look to client satisfaction or feedback, a smiling face on a happy customer, a willingness to co-produce, and increases in trust of the public enterprise and its officials (Moore 1995, pp. 186-7).

Worryingly, this model is one-sided. There is no real conception of 'negative public value', where even well-intentioned innovations can lead to deteriorating service delivery, or create increasing expectations that agencies cannot meet. There is no conception of the 'mobilization of bias' (Schattschneider 1960) and the ways in which minorities can be organized out of the political arena. The simple point is that Moore envisages a one-way benevolent conception of public value. But there are many publics, not one, and the public interest is endlessly contested. Value conflict lies at its heart. Consensus is elusive. To remove it from the formal political process is to attenuate accountability and to place public servants in a position of power without responsibility.

Throughout our discussion of the confusions and assumptions in the public value approach we have stressed we are talking about Westminster parliamentary government. Our last two points about the primacy of party politics and the public interest lie at the heart of our argument. We believe the inbuilt hierarchy of Westminster systems, coupled with the disciplined party politics, imposes severe limits on both the role of public servants 
and the utility of the public value approach. So we now return to these two arguments in more detail.

\section{DILEMMAS}

\section{The primacy of party politics}

To draw an elementary distinction, Moore takes large ' $\mathrm{P}$ ' politics or party politics and consigns it to the authorizing environment. He then focuses on the small ' $\mathrm{p}$ ' politics of the bureaucracy and the way in which public managers manage their proximate environment. But in hierarchic Westminster systems with disciplined party systems, and in sharp contrast to the loose pluralist party system of the US, large ' $\mathrm{P}$ ' politics frames the decision structures for small ' $\mathrm{p}$ ' politics.

In effect, for Moore, politics operates in its own insular realm removed from the operational efforts of managers. Politics is distanced from the operational leadership role of the manager. This view downgrades politics. It allows politics to enter his examples only as retrospective agreement or as a belated form of authorization (tied to after the fact legitimacy). Although he talks often of politics and stresses the need for managers to recognize (or read) the political landscape, he is uncomfortable with the operations of politics in liberal democracies. He is critical of the conventional theories of democratic administration on many grounds at many points in the book (Moore 1995, pp. 16-17; 31-6; 48-9 and 54-5). Formal politics works to its own expedient logics and does not fit easily with the managerial endeavour. It is evasive and does not 'deliver' for the public good but 'seems focused on winning votes by satisfying special interests rather than on finding and producing something publicly valuable' (Moore 1995, p. 19). Formal big ' $\mathrm{P}^{\prime}$ politics is risk averse and does not encourage the quest for public value.

He is also critical of the behaviour and motivations of politicians, and assumes society distrusts both politics and politicians (see Moore 1995, pp. 31-3, 54, 179, 330, 338, 349). Politics is venal and expedient (shades of Tammany Hall). Politicians are villains who wield political power temporarily but do not defend the public sector. They may be able to authorize, fund and monitor (indeed, he occasionally refers to them purely as the 'authorizers'; Moore 1995, p. 55), but often they cannot prioritize or give government agencies clear mandates or directions. So, managers need to fill this political void. He also sees public administrators relying on traditional doctrines about the role of politicians. Thus, the politicians impose a dysfunctional hierarchic mind-set on managers 'downward toward the reliable control of organizational operations' (Moore 1995, p. 17). He is critical of politicians playing this hierarchic role because it saps bureaucracy of imagination, making it reactive and small ' $c$ ' conservative (by contrast, see Goodsell 1985; Olsen 2005). Politics impedes innovation in the public sector, imposes constraints on managers - they 'have to be reined in more tightly than private sector managers' (Moore 1995, p. 19) - and it limits the scope for outward entrepreneurship to achieve 'valuable results'. In one sense, if public managers adopt a public value approach they are being asked to rebel against standard politics and usurp the democratic will of governments. Moore comes closest to admitting this when he advises managers to orient themselves upwards to renegotiate policy mandates (that is, overturn the political wishes of elected officials, Moore 1995, p. 17; italics added). This point was recognized by Stoker (2005, pp. 55-6) as a 'key dilemma' when 'management is king, and politics is sidelined'.

Moore also asserts that markets are preferable to government interference, because individual preferences can be satisfied, and that individual liberty is preferred to collective 
goals. In the US, with its preference for smaller, cost-effective government, he suggests officials have to make a convincing case for intervention because any resources needed 'are only grudgingly surrendered' (Moore 1995, p. 29). In turn, this reluctance then means that:

it is not enough to say that public managers create results that are valued; they must be able to show that the results obtained are worth the cost of private consumption and unrestrained liberty foregone in producing the desirable results. (Moore 1995, p. 29)

Managers can dream but they must turn their dreams into reality, so:

if managers have substantially valuable ideas but are unable to attract political support or administer them feasibly, then those ideas must fail as strategic conceptions. (Moore 1995, pp. 71-2)

In addition, for political management:

building support and legitimacy for a policy, or of enhancing the effective claim that an official may make on the society at large, is what political management is all about . . . managers must work to fashion legitimacy and support for themselves, their policies, or their organizational strategies. (Moore 1995, pp. 112-13)

Crucially, managers require sanction from authorizing actors; they

need these 'external' [authorising] actors for one (or both) of the following reasons: they need their permission to use public resources in pursuit of a given enterprise; or they need their operational assistance to help produce the results for which they are responsible. (Moore 1995, p. 113)

The eventual 'authorizers' are external to both policy formulation and management; they pale into insignificance conforming more to the role of innocent bystanders.

Moore does not pretend we live in an apolitical world. He recognizes other powerful stakeholders and the wider political context. But his main point here is that such 'external' politics should be 'managed' by the public managers. So, he treats politics by compartmentalizing it into two discrete junctures with which managers need to engage. First, he recognizes that public managers cannot be unilateral actors exercising unrestrained bureaucratic leadership, so some form of oversight and public legitimizing is necessary. He writes in frustration that managers 'know full well that there is no escape from the powerful mechanisms of political oversight' (Moore 1994, p. 296). So, he builds a stage which he calls 'the authorizing environment' and confines democratic (and authoritative) politics to this narrower realm. He defines the authorizing environment as comprised of 'external actors beyond the scope of their [the managers] authority' (Moore 1995, pp. 113-14). Entrepreneurial managers, then, need to gain assurances they have permission (authority and money) and operational assistance. Politics now is not all pervasive but has become encapsulated as 'approval' and 'continuing consent'.

Second, he talks about small ' $p$ ' politics taking place in the operational networks in which managers find themselves. Managers have to persuade other significant actors of the merits of their case and the value of the ends they propose. They have to negotiate the micropolitics of place and opportunity, seeking agreement, aligning interests, and building coalitions. Politics is dialogue, but initiated by the line manager. It is about line managers promoting end strategies and crafting agreements. But if Lindblom (1990) is to be believed, agreement is the key criterion of success, and agreement will be about means not ends. 
This characterization of politics may fit some presidential systems but we suggest that in Westminster and other systems of parliamentary government, politics are inherent in all the situations and choices managers make, and in the choices others make that impact on the manager. We should be clear, and managers should recognize for their own good, that they are being asked to play a high-risk political game. It can get nasty, bite them back, leave them exposed, and perhaps destroy their careers (for further discussion, see below). They are not protected if they assume such political roles. Public value initiatives can just as easily serve powerful bureaucratic interests as they can the citizens' interests; can just as easily impose costs as produce benefits. Community acceptance of the value-added is not the only test of value, it may be temporal, contextual, and it may be fickle (this point is recognized by Moore 1994, pp. 297, 1995, p. 72).

Moreover, by distancing the authorizing environment from the policy process, Moore's description resembles not the political life of bargaining and deals, but an aloof judicial bench arbitrating on ideas or granting legitimacy to managerial proposals. In Westminster systems, the roles of members of the authorizing environment are not confined to 'authorizing' the actions of public bodies and non-elected officials. It is as likely they will argue, disagree, compete and behave inconsistently. The manager may need their cooperation, not just their 'authorization'. Yet Moore uses the idea of the 'authorizing environment' to encompass not only building constituencies and interagency collaboration, but also all the stages of formal accountability buried in the simple notion of 'needing permission'.

Of course, in Westminster systems, significant actors exist who are charged to serve in these specific roles - ministers and prime ministers. Yet Moore puts these actors to one side or consigns them simply to overseeing functions. Contrary to Moore's depiction, ministers and politicians are not merely end-users of public value that has been imagined by line managers, but are themselves significant initiators of policy choices. Leadership in disciplined party systems is well placed to impose its choices. Ministers are expected and expect to play the political game and shoulder the accountability. Ministers and their senior advisers would be perplexed (not to mention offended) to read they were mere authorizers of decisions formulated and framed elsewhere. Westminster systems are hierarchical, not pluralist; ministers believe in hierarchy, and the party system allows them to impose their choices. From their perspective, they are involved in agenda-setting, initiating policy proposals, formulating and lobbying for proposals, brokering deals, fighting for funds, and authorizing and announcing. They are assisted by officials who owe their commitment and loyalty to the minister. Moore's account does not describe their worldview, let alone credit them with any of these functions. Nor does his view pay enough attention to the limits that loyalty to the minister places on the scope for initiative by public managers. Loyalty is a pre-eminent virtue. Disloyalty is simply not tolerated. One person's initiative is another's disloyal act. Bureaucratic entrepreneur beware.

\section{The public interest}

For Moore, the preferences of public managers about the public interest will normally prevail. It is their responsibility to initiate and manage the dialogue with stakeholders. Thus:

Society needs leadership from these managers to help it learn what is both desirable and possible to do in public domains for which these managers are temporarily responsible ... in most cases there is more discretion than most public managers (and their 
overseers) acknowledge. Nearly always, the politics surrounding a public enterprise are sufficiently contentious to suggest several different plausible and sustainable conceptions of public value. (Moore 1995, p. 63; original italics)

But who gave these platonic guardians the right to choose between these conceptions of the public good? How do we hold them to account when it goes wrong? This conundrum is the second dilemma at the heart of the public value approach.

The seeming popularity of Moore's approach may excite renewed debate over the notion of the 'public interest', a debate which has long been out of academic favour. We should remind ourselves that Schubert (1960, pp. 199-206) identified three conceptions of the public interest - rationalist, idealist and realist. Rationalists postulate a commonweal expressed in the popular will, articulated through for example a two-party system, and faithfully executed by public officials. Idealists support the 'true' interests of the public that reside in a higher, natural law interpreted by public officials. Realists see the public interest as the result of pluralist bargaining. Moore's view is principally idealist with an unwelcome dab of realism.

We prefer the notion that the public interest has different meanings in different narratives. It is constructed within political traditions that offer distinct and distinctive narratives. It is possible to identify at least three traditions.

In the market tradition, as Peters (1996, p. 43) argues, the public interest requires governments to be judged according to how cheaply public services are delivered and how they respond to market signals. Citizens are seen 'as consumers as well as taxpayers', even if accountability is often difficult to identify. Hence, 'the public interest can be served by allowing citizens to exercise freer choice in a market for public services' (Peters 1996, p. 44), meaning the public interest is 'low cost'. According to Peters (1996, p. 87), such flexible government has 'the least clearly articulated concept of the public interest'.

In the bureaucratic tradition, the public interest approximates Schubert's rationalist notion. The minister articulates the common will as a member of the elected majority party, and the role of the public servant is to put the minister's wishes into practice. This approach is a constitutional version of the public interest. In Britain, it means: 'the duty of the individual civil servant is first and foremost to the Minister of the Crown who is in charge of the department in which he or she is serving' (Armstrong 1985). Public duty takes precedence over private interests. The individual civil servant should contribute to the greater good and be anonymous and unselfish. Chapman (1988, p. 38) comments that civil servants had 'a disposition to find public affairs of interest; no desire or intention to take part in political life; and a readiness to work as a member of a team, rather than seek personal glory'. In Britain, for instance, the civil service culture is considered to be a blend of values including honesty, loyalty, impartiality, propriety and a respect for intelligence, with conservatism, scepticism, elitism and arrogance thrown in as 'extras' (by contrast, see Butler 1992, p. 8; Plowden 1994, pp. 21-3, 74).

A third participative tradition stresses dialogue among actors and groups. For example, Wamsley et al. (1990) define the public interest as both an ideal and a process, meaning it is the product of a continuing dialogue between all affected individuals and groups that addresses long-range views, competing demands. Officials are trustees of the quest for the public good. It is their responsibility to look beyond the short-term, to stimulate reasoned debate, to involve citizens in that debate, and to expand the opportunities for involvement. They are the repository of 'specialized knowledge, historical experience, time-tested wisdom and . . . some degree of consensus of the public interest' (Goodsell 
1985, p. 155). Officials act as a counterweight to short-term political expediency and opportunism. They stand for integrity and probity against the possibility of partisan interest and corruption through dialogue and joint action with citizens playing a key role in constructing a shared interpretation of the public interest values.

Just as the public interest is variously constructed, so is the idea of public value. Public value is not 'a given'; nor is it merely about doing good things today. We suggest that notions of the public interest and public value need to take the following into account.

First, if public value has meaning, it is a shared meaning that operates within a narrative and its associated tradition. The shared meaning develops iteratively and collaboratively; it emerges through dialogue and reconfirmation in society.

Second, private definitions of public value (or assertions from single actors that this or that will add to public value) are flawed. No one actor can impose a definition of public value. There are invariably several publics. It is impossible to define presumptively the substantive content of public value.

Third, government actors (politicians and officials) cannot unilaterally command public value, but must work through others, using the skills of diplomacy, negotiation, and mediation (a point conceded by Moore (1995, pp. 179-82) in his brief discussion of public deliberation). Accordingly, instead of attempting to determine (and usurp) the public interest, officials may play a more valuable role in monitoring and overseeing the process of public dialogue. Although they may have their own preferences (and can engage in the shared narrative contributing to the meaning of the public interest), public officials can become the guardians of process, not content, working with shared meanings of the public interest and shared understandings about their roles. They may be bearers of legality, disinterested in outcomes, and motivated by honesty and integrity. They can act as counterweights to partisan interests. They remain a repository of institutional scepticism. Officials can become trustees of knowledge, experience and expertise. They can serve as protectors of the longer view. They may also have a role in addressing procedural issues of equity involving the under-represented or the ignored.

\section{ILLUMINATING THE DILEMMAS}

We adopt Moore's own style of argument to illustrate the dilemmas for managers in adopting public value approaches. Just as Moore chooses his cases to illustrate innovative or value creating behaviour by public officials (usually from the low risk end), so we have chosen five recent cases from Australia, Britain and New Zealand to illustrate the malign, mendacious, dangerous, unpredictable and tragic effects of such behaviour. Our cases are chosen from the hard end of the administrative spectrum because they deal with difficult choices, conflicting demands, and vicissitudes of politics. We realize that there can be various legitimate interpretations for these cases; not a single, definitive account. We are not suggesting that our account is the only version of the events. But we submit that the interpretation we recount is both realistic and plausible, and highlights the dangers of public officials acting beyond their legitimate roles. In each case, we contend, public officials were attempting to do what they thought was the right thing, adding public value, going the extra yard, using their expertise creatively. In each case this attitude did not help them; indeed, it made circumstances worse. We also draw some lessons from these cases to persuade managers to temper their enthusiasms.

Simply because we have chosen these cases to illustrate the dark side of public administration, it should not be assumed that we share Moore's bleak assessment of 
politics. Politics is Janus-faced. So, political parties and elected political leaders are both the wellspring of many policy innovations that make a great difference to many people's lives as well as self-serving electioneers placating special interests and favouring shortterm palliatives over longer-term solutions. Here, we are not exploring the virtues or sins of political leaders. We focus on the dangers for public officials of challenging, supplanting and undermining those leaders. With this aim in mind, our cases illustrate the following propositions.

1. Governments are not inherently benign - political leaders will often seek to protect themselves at the expense of their officials (the David Kelly case from the UK).

2. Spearheading decisions and 'doing the politics' for a minister is dangerous territory - 'excessive responsiveness' leads to public servants being criticized for unethical or unduly partisan behaviour (the 'children overboard' case from Australia).

3. Authorizing environments can be wicked and mendacious - they display the pervasive characteristics and deleterious effects of partisan self-interest - and the political courtiers not the officials remain king (the 'mad cow disease' case from the UK).

4. The public sector is fundamentally different - there are real dilemmas in copying private sector behaviours (the 'Yorkshire tea-parties' case from the UK).

5. Taking the entrepreneurial initiative can lead to both unintended consequences and the problem of 'many hands' - the tragic consequences of public value explorers behaving without clear lines of accountability (the Cave Creek case from New Zealand).

\section{David Kelly: governments are not benign}

This story is part of a larger story - the decision to invade Iraq in 2003. Part of that process was to gather evidence on the military threat posed by Saddam Hussein's regime. A key claim in that assessment was that Iraq had weapons of mass destruction that could target the West. The first story focuses on how the British government dealt with a troublesome civil servant while gathering evidence justifying the decision to invade Iraq.

David Kelly was an official in the Ministry of Defence (MoD). He was a biological weapons expert who had worked for the United Nations in Iraq. In 2002, he advised on, but did not write any part of, the dossier compiled by the Cabinet Office's Joint Intelligence Committee which advised the prime minister, Tony Blair, on weapons of mass destruction in Iraq. He did not accept the claim (made in the dossier) that Iraq had the capability to launch battlefield biological and chemical weapons in 45 minutes. Kelly's job involved briefing the media and on 22 May 2003 he met Andrew Gilligan, a BBC journalist. The meeting was on a 'not for attribution basis' and Kelly voiced his doubts about the 45-minute claim. Gilligan broadcast this claim on 29 May on the Today program, including the allegation that 'Downing Street . . . ordered it [the dossier] to be sexed up' by including the 45-minute claim (see Rogers 2004, Appendices 1 and 2). All hell broke loose.

On 30 June, as the political furore showed no sign of abating, Kelly told his manager at $\mathrm{MoD}$ about his meeting with Gilligan. The ensuing meetings, and who said what to whom, matter not because the result is clear (see House of Commons 2004). MoD decided to admit that the source of Gilligan's story worked at the MoD and gave enough information for journalists to make an informed guess as to Kelly's identity. Contrary to their normal practice, when journalists asked the direct question, MoD confirmed Kelly 
was the source. Michael Evans, defence editor of The Times, put 21 names to the MoD to get Kelly's identity confirmed (Rogers 2004, p. i).

Although Blair claimed, 'Nobody was authorized to name David Kelly', Sir Kevin Tebbit, Permanent Secretary of the MoD, told the Hutton Inquiry the decisive meeting took place at No. 10 on 8 July 2003:

A policy decision on the handling of this matter had not been taken until the Prime Minister's meeting. It was only after that that any of the press people had an authoritative basis on which to proceed.

The meeting also decided that the MoD should proceed as follows: prepare a press release with details of Kelly's background; issue a question-and-answer briefing that provided more clues to Kelly's identity; and confirm Kelly's name if it was put to them. In the purple prose of his diaries, the Prime Minister's Director of Communications, Alastair Campbell, admitted the aim was to 'fuck Gilligan' in his war with the BBC (Rogers 2004, pp. 6, 265).

The public pressure on Kelly was unremitting. MoD gave him a formal warning for his unauthorized meeting with Gilligan. On 15 July, he appeared before the House of Commons Foreign Affairs Select Committee. On 16 July he appeared before the Intelligence and Security Committee. On 17 July he went for a walk in the woods near his home where he committed suicide by cutting his left wrist.

The government responded by setting up an Inquiry chaired by Lord Hutton. His report concluded that no one could have anticipated Kelly's death and that the MoD behaved properly in confirming Kelly's identity (House of Commons 2004). Ministers could not believe their luck. Although Hutton agreed that Blair chaired meetings about naming Kelly, he still concluded it 'was not part of a covert strategy to leak his name'. To use The Spectator's rhetorical question: 'What did he [Lord Hutton] think was discussed at these meetings?' (31 January 2004). For the government that was the end of the matter. For David Kelly's family it was clear 'the government made a conscious decision to cause Dr Kelly's identity to be revealed and it did so to assist it in the battle with the BBC'. They were not alone in their disbelief. For many others, the Hutton Report bordered on official apologia and left too many unanswered questions (see Rogers 2004, p. 306).

Our concern is neither the dossier on Iraq, nor the Hutton Report, nor whether Kelly committed suicide. All of these issues are important and complex. We want to make a brutally simple point: working for government can be dangerous to the point of being lethal. Governments are not benign. So, any public manager of entrepreneurial bent had better be careful. Stress, peace of mind, your job and economic security could all be on the line. What is politically expedient will be done. It was expedient to name Kelly, so he was named: thrown to the wolves in effect. This example may be extreme but history is littered with the wrecked careers of public officials. Officials are risk averse with good reason. Politicians have a strong instinct for self-preservation, not for saving their officials. They can be wilful, mercurial, and, above all, powerful. And David Kelly was correct. Saddam Hussein could not launch biological and chemical weapons within 45 minutes.

The proposition we would extract from this case is that speaking truth to power is not dangerous, it is potentially deadly. 


\section{Children overboard: the dangers of 'doing the politics for them' or 'excessive responsiveness'}

In 2001, in the lead up to a federal election, a scandal broke over the Coalition government in Australia's claims that illegal refugees trying to land on Australian territory had thrown their children overboard as a means of gaining rescue and asylum. This statement was made although early oral reports by the navy from the scene said that an asylum seeker on a sinking vessel had held up one child in a life jacket (possibly to show they were carrying children). As the messages were passed back to Canberra, however, the story became exaggerated. Instead of a possible threat to one child, the phone messages back to the prime ministers department stated men had jumped into the water and 'children' had been 'thrown overboard' by the asylum seekers. Senior departmental officials immediately briefed ministers and within a few hours of the events being reported, three senior ministers made inflammatory public statements claiming, as fact, that children had been thrown overboard.

The Attorney-General, Philip Ruddock, told the media that children had been thrown overboard and that this was one of the 'most disturbing practices I've come across in public life' (see Parliament of Australia 2002; Weller 2002; Marr and Wilkinson 2003). The Prime Minister, John Howard, spoke on radio about 'suggestions that children were thrown overboard'. Two days later the Defence Minister Peter Reith released video footage of asylum seekers in the water (because, as was shown later, their boat was sinking). Within days the military and Defence Department knew the claims made by the politicians were not true and that they had misrepresented the situation for their own political ends (making border protection a salient election issue). Thus, the Defence Minister, Peter Reith, when told by senior military officers that the video did NOT show the children being thrown overboard, commented, 'Well, we had better not see the video then' (Marr and Wilkinson 2003, p. 255).

The scandal that emerged after the election was not so much about the accuracy or inaccuracy of the initial reports, but about why no correction was made within days once the story was known by many officials to be incorrect. The 'story' was allowed to run because it advantaged the government and emphasized the government's tough attitude to the asylum seeker problem. At a later Senate investigation it transpired that senior officials had known but had either failed to inform ministers of the truth, or had not tried diligently to draw the facts to the ministers' attention. The prime minister and other senior ministers probably knew and certainly suspected that the events had not happened as had been claimed. But they simply went quiet on the issue (allowing it to run on in the media), and did not ask probing questions of their officials or advisers. Ministers initially hid behind phrases such as 'I have been advised that. . . ', 'I was acting on advice given to me. . ', or 'I am told that. . .'. Later, on the issue of why they did not offer a correction, the ministers would use other terminology to deny they knew - such as 'I was not formally advised . . .' or 'I did not know . . .'.

Later some officials did go public claiming to have advised senior ministers or their advisers by phone or in some form of written communication, but this apparently did not constitute 'formal advice' according to the ministers, and both parties tended to have different recollections of what was said or what was received. Ministers perfected a culture of 'plausible deniability', and officials were encouraged to say as little on the public record as possible.

The whole incident was highly charged because of the election. But it is clear some officials became politically aligned in that they made assumptions about what ministers 
wanted to hear, or not hear, and did the political bidding of ministers. By acting politically behind the scenes, these officials evaded the forms of accountability applying to ministers. It is clear there was some blurring of roles between officials, advisers and ministers. It is clear these officials strayed into providing 'selective' advice and their behaviour was subsequently judged as unethical and partisan by many observers. It would be surprising if these 'excessively responsive' officials, who did the politics for the minister, survived a change of government. They aligned themselves too closely with the government's political strategy and politicized their positions, bringing the professionalism of the public service into question. Some attempt to patch over these problems was made in the aftermath, with senior public servants stressing the need for good record-keeping and separating facts from opinions in advice (something once considered the standard currency of good public administration).

The proposition we might make from this case is that if the public service becomes too politically aligned with the political interests of the government, it risks getting badly burnt as well as losing its credibility.

\section{Mad cow disease: authorizing environments are mendacious}

The story of Bovine Spongiform Encephalopathy (BSE), 'mad cow disease', dates from 1986 when a case was first identified in Britain (see BSE Inquiry Report 2000; Packer 2006). Our part of the story dates from March 1996 when the European Union (EU) introduced an export ban on British beef because BSE was linked to Creutzfeld-Jacob Disease (CJD) in humans. The framework for lifting this ban was agreed in June 1996 in Florence. When the Labour government came to power in May 1997, lifting the beef ban was a priority for the prime minister and, therefore, for the new minister at the Ministry of Agriculture Fisheries and Food (MAFF), Jack Cunningham. The problem was the Florence Agreement, which was an effective straightjacket to the rapid repealing of the ban because it gave other members states many opportunities for delay. The minister understood the situation and briefed No. 10. MAFF negotiated with the EU Commission about lifting the ban but the Commission's sensitivity to the wishes of other member states, who did not want it lifted, was a major obstacle. No. 10 was exasperated and continued to insist on rapid progress, ignoring the technical obstacles and the inconvenient fact that the Commission, not MAFF, controlled the process. The then permanent secretary at MAFF, Sir Richard Packer, was frustrated by the lack of understanding:

In March 1998 Blair had had less than a year in government and his experience of the EU was of the same limited duration. He felt able, however, to be so confident of his own judgement of what could be achieved in EU forums on a highly technical issue a judgement that happened to coincide with his wishes - to conclude that those who advised him differently, some of them with decades of EU experience to guide them, were culpable and merited reproof. (Packer 2006, p. 226)

If Blair's stubbornness on this issue flew in the face of the best advice, he was at least consistent. Continuing research on BSE revealed that the disease might be transmitted by beef cuts on the bone. Cunningham was publicly committed to a strategy of visibly protecting the consumer and, on the advice of the Chief Medical Officer for England, the retail sale of beef on the bone was banned.

It had become apparent by this time that since May Downing Street liked to be much more closely involved in routine Ministerial decisions than had previously been 
customary. It was, therefore, sensibly deemed expedient to alert Downing Street to what was proposed. A reply came quickly back to confirm that the Prime Minister was content. (Packer 2006, p. 220)

But the ban produced an outcry. It was seen as overprotective. No. 10 responded immediately to public opinion by 'agitating for the beef-on-the-bone ban to be lifted' while acting duplicitously against MAFF and in particular its permanent head. The actions had been approved by the Prime Minister (Packer 2006, p. 220).

Spin tactics were then used to displace any 'blame' from the government to individuals. In December 1997, the government announced an Inquiry into BSE. As the Inquiry progressed, so did the number of articles in the national newspaper, the Daily Express, attacking the permanent secretary at MAFF (see 21 October 1998). A member of the Labour Party told Packer:

Their articles were not accidental; there was an underlying purpose. In her view the obvious explanation was that I was being deliberately set up as the 'fall guy' for the forthcoming Report of the BSE Inquiry. It was standard New Labour practice to decide on who should be categorized as a villain . . . and to take steps well beforehand so that their depiction in that guise rang true when the time came.

Packer was told not to be naïve or underestimate 'the ruthlessness of New Labour'. It did not matter whether Packer was the real villain, only that he 'would be a credible person if cast in that light'. The attacks continued after Packer left the service and the 'government. . . let it be known quietly that since I had left the service there was no more need to look for a culprit for BSE'. The BSE Inquiry Report (2000) did not single out Packer for criticism. Such deception, euphemistically known as 'spin', is an established part of New Labour's armoury and, we venture to suggest, most present-day governments (all quotes are from Packer 2006, pp. 232-43).

This case suggests that the 'public interest' and, by extension public value, is whatever the prime minister says it is. The expression 'authorizing environment' is indeed a euphemism for an array of behaviours, many of which are not susceptible to management. The authorizing environment may not give a jot for evidence or due process. It can change its mind or contradict itself at the first gripe of public opinion. It may not play fair; it may use duplicitous tactics and speak falsely. It can allot blame when things go against its wishes, and attempt to evade any blame itself on the 'not me guv' principle. Indeed, the phrase 'authorizing environment' sounds like a polite euphemism for something that only uses politeness to disguise aggression and to disarm various opponents. We would suggest that the term originates from the language of business schools - implying chief executives and directors approving strategies in which they all have an interest. Political scientists would not use such a term to describe the court politics of power.

The fall of Packer also reminds us that department heads in parliamentary systems are not American-style agency heads who have to build winning coalitions. They are extensions of their ministers. They are in regular and sometimes daily contact with their political masters and generally occupy rooms nearby. The traditional model of public administration may have its limits, but its strength lies in protecting the individual public servant from naming, and checks and balances exist to curb the arbitrary exercise of power. 
Our proposition from this case is that the greater the need for political-management skills, the more dangerous it is for public servants. Or, more vividly, you cannot managerialize political power because it is like taunting a Rottweiller.

The public sector is different: eating out with the Yorkshire Regional Health Authority In 1997, the UK Committee of Public Accounts (1997) reported that public executives of the Yorkshire Regional Health Authority had paid invoices totalling £ 694,909 over two years for dinners and entertainment (Committee of Public Accounts 1997). The events included copious amounts of alcohol. The committee criticized the authority's enjoyment of some of life's little luxuries, and expressed concern over a further eight instances of 'unacceptable' behaviour which they noted 'with surprise' and 'serious concern', and on one occasion they were 'appalled'. The committee found that remedial action was insufficient and 'deeply unsatisfactory'.

Their use of such uncharacteristically strong language was triggered by several serious transgressions. Nearly half a million pounds had been paid in irregular relocation expenses to senior managers. Staff were engaged on improper contracts, and severance payments were made to departing managers without the necessary approval. The former personnel director had negotiated a new contract for themselves three days before the demise of the authority, leading the committee to conclude 'her actions seemed to have been intended to maximise her own reward'. While the rules did not allow the authority to provide a car for the chair, they nevertheless provided one (which was sold later at a loss of $£ 10,000)$. The chair's salary was paid gross through his company, contrary to the advice of both the NHS Executive and the Inland Revenue. Contrary to EU law, a contract was signed with a US healthcare company without tender, as was a lucrative contract with Yorkshire Water for waste incineration. Land was disposed of at massive losses. In a clear conflict of interest, one senior manager awarded large contracts to a company owned by her husband. Many other examples of financial mismanagement were also recorded.

The committee was critical that little remedial action was taken. One manager was given a 'severe reprimand'. But because the authority no longer existed, the NHS Executive concluded that neither it nor the current employing authority could take legal or disciplinary action against any of the individuals involved. The committee thought it 'deeply unsatisfactory that so little of the money improperly paid ... had been recovered'.

This descent into unacceptable behaviour occurred in the health sector - a policy network notorious for its domination by health professionals. More recently, their influence has been challenged by an injection of managerialism. Thus, the general manager defended his actions by arguing he brought a more commercial attitude and a willingness to embrace risk to health services management. He was going with the flow of a more relaxed regulatory framework and with encouragement from the highest levels. The committee rejected his view, arguing it was possible to combine the 'honest handing of public money' with 'effective programmes for promoting economy and efficiency'.

If no one transgression by the authority was dramatic, the catalogue is eye-catching. The authority embraced the culture of the day, neglected its classic stewardship role, and got away with it for several years. Control was not exerted. No one was brought to account for the substantial waste of public money. The money was not recovered. Moreover, the Yorkshire example cannot be dismissed as a single, aberrant case. The committee 
found similar cultures in two other health authorities. They were all encouraged by the NHS Executive by the NHS Executive to embrace the managerial ethos of the day. The committee's report shows private government in action, clear control deficits and lack of network accountability. It is the antithesis of the public interest.

The proposition we would draw from this case is that you cannot directly transfer private sector practices into the public sector and hope to escape scrutiny. That scrutiny will reject practice acceptable in the private sector. Public money is different.

\section{The Cave Creek Tragedy: entrepreneurs and too many hands}

In 1995, a viewing platform in New Zealand collapsed into a 30-metre deep limestone chasm killing 14 people. Under tight budgets and a hard-line, neo-liberal public management regime, officers of the Department of Conservation were attempting to increase tourism numbers to the West Coast while preserving the fragile limestone landscape. They acted on their own initiative in constructing the platform. They were not approved builders. They had limited experience in engineering. They erected the viewing platform without the required approvals and permits. Crucially, they erected it without mooring bolts to secure it to the rock face. Instead they used nails! (Noble 1995; Gregory 1998; ANZSOG 2004).

A group of 18 students were on the platform when it tore from its base and fell into the cave. The immediate cause was the poor design and construction of the cantilever platform, but the resulting Public Inquiry found a litany of negligence and poor oversight. The government was blamed for giving the department inadequate resources. The judge heading the Inquiry argued the department had been 'malformed' from the outset because it had contradictory objectives and did not have good internal processes of control. At the Inquiry no one would accept that they were 'in charge' or accept responsibility for the decisions taken - all the key actors thought someone else was in command. Although the Inquiry identified poor platform construction as the primary cause of the tragedy it also identified six administrative secondary causes.

Neither the CEO nor the minister resigned in the immediate aftermath. Indeed, the minister invented a new Westminster convention saying: 'I gave a commitment to implement ministerial responsibility rather than shrink from it by resigning' (Press Release 30 May 1996). The Inquiry did not blame individuals but stated that the collapse was due to 'institutional failure' - they were 'doing their best' but 'not one of the individuals concerned was ever aware of the appropriate standards'. The minister eventually resigned in mid-1996 while the CEO continued until May 1997 seeing a change management process through and a new executive appointed.

Although Cave Creek appears as an unfortunate accident, it was largely caused by public entrepreneurs seeking to create public value. Bovens (1998, p. 46) identifies the 'problem of many hands' where responsibility for policy in complex organizations is shared and it is correspondingly difficult to find out who is responsible. The proposition from this case is that public value innovations by amateurs can magnify such accountability deficits in public administration.

\section{CONCLUSIONS}

Arguably, public value approaches have provided a much-needed boost to theories of public administration. Such a philosophical challenge has not been seen since neo-liberal and public choice theories revolutionized public management in the 1980s. The theory 
holds the public sector in high esteem, which partly explains why the approach was so readily embraced by middle to senior public servants in constitutional bureaucracy. They want to restore some pride in their profession, to be acknowledged for doing good work, and to regain some self-worth and intrinsic reward for their public service. We do not find governments and politicians lauding the praises of public value approaches. Rather, we find the discourse driven by academics genuinely committed to the ethos of public service, by think-tanks sympathetic to government provision and social justice, and by operational managers who see it as offering a new set of navigational reference points with which to navigate the ups and downs of public policy.

However, although public value may bring benefits to government organizations and the community, it is never clear what criteria or whose standpoint form the basis for judging the efficacy of public value or its long-term measurability. Moore's examples often lead to some social good, but, equally, most are examples that benefit the host organization. They help to get caseload targets achieved, improve service delivery, enhance organizational relevance, and ease outreach burdens. It is a question of balance and emphasis. If Moore's argument is about 'how do public managers increase public value' then our concerns stand. If, however, his focus in on 'how do public managers increase the value of their services to the public' then many of our objections are less relevant (see our proposal for a 'ladder of public value' in Rhodes and Wanna 2007).

There is no inherent problem with highlighting the need for innovation and for political management as essential skills in modern public administration. They are necessary irrespective of whether or not public managers address the issue of public value. There is value in low-risk operational innovations. So, we can clear up Moore's two confusions by stipulating that 'public value' is best regarded as a tool used by public servants to identify and implement operational improvements at the workplace. But, in addition, we must be clear in defining the expected role of the 'public manager - a label that, in Westminster systems, refers only to non-elected neutral officials.

If we see public value as a theory that anoints not only elected but also unelected public managers as the platonic guardians of the public interest, and normatively endorses this position, then the approach encourages managers to usurp the democratic will. It is a repackaging of bureaucratic self-interest. In public value approaches, public servants are encouraged to bypass the conventions of democratic politics and rely on their idea of what is in the public interest.

Moore's book is an example of how both business schools and the discipline of management view politics. It is a problem to be managed by 'their' rules and processes; by the strategic triangle. But in a democratic polity only politicians and the polity can determine those rules and processes. Politics may be messy, economically irrational, slow to innovate, but it is primary not an 'add-on'. If Moore's book represents the view from where the manager sits, what does the world of public value look like from where the political executive sits? It looks like another theory of politics in which 'exploring' public managers take risks for which the elected executive is accountable.

Politics is ever present. It cannot be contained or sidelined merely to an add-on 'authorizing environment'. Politics is not just something to 'be managed' by public managers. In reality, politics and management co-exist in given contexts and with specific actors. Politicians can exercise different dimensions of power, will have different motivations and pressures on them, and can use different tactics at different times. They are far from powerless arbiters of managerial entrepreneurialism. It is fundamental that they remain accountable for public policy decisions. We agree with Aaron Wildavsky, 
writing back in 1968 about the then fashionable management reforms of PPBS, when he vigorously defended the primacy of politics:

political rationality is the fundamental kind of reason because it deals with the preservation and improvement of decision structures, and decision structures are the source of all decisions. . . . There can be no conflict between political rationality and ... technical, legal, social, or economic rationality, because the solution of political problems makes possible an attack on any other problems, while a serious political deficiency can prevent or undo all other problem solving. (Wildavsky 1968, p. 393, citing Diesing 1962, pp. 198 and 203-4)

We argue the public value approach needs to be appraised in its historical setting as a fashionable 'reinvention' of government following the era of new public management. It is part of a search to improve the standing of the public service; to restore the legitimacy of public action. But when public officials are encouraged to by-pass the conventions of democratic politics and impose their views about the public interest, then the public value approach has inherent problems that need to be recognized before it is adopted without question into non-American contexts. How do we control these new platonic guardians? Ultimately politicians remain responsible and accountable for whatever outcomes are attempted, even if these outcomes only happen some time later.

We are not alone in criticizing the suitability of public value reforms in Westminster parliamentary systems. Both academics and practitioners see the force of our argument. Davis and West (2009) comment that 'Rhodes and Wanna's (2007) observation that Moore's work has been taken up rather hastily and inappropriately generalized to governmental systems with quite alien organising principles is surely correct'. Gains and Stoker (2009) argue that public value must 'acknowledge and embrace the realities and politics and political relationships' and suggest it is more applicable in local level network governance than under the old club rules of the Westminster model. Practitioners forcibly sound a note of caution and we leave the last word to them. Peter Shergold (2008), former secretary of the Australian Department of Prime Minister and Cabinet, emphatically points out that inside influence comes with clear obligations. The public service, he emphasizes,

is not a career that is suited to everyone. It offers the opportunity to work from the inside but always in a manner that is responsive to the direction set by government. . . . It is for elected Ministers, individually and collectively, to establish their view of the public interest and to be held responsible for it at the ballot box. Public servants who come to believe, intellectually or ethically, that they have a view of the national interest superior to that of the elected government needs to leave and enjoy the freedom of pursuing policy goals from the outside.

Similarly, Michael Wintringham (2008), former head of the New Zealand State Services Commission, observed that ministers 'are not our friends' and the relationship 'requires careful boundary management' because:

The boundary where responsiveness and independence rub along together is far from tidy. It is where politics (sometimes pretty raw politics); public law; employment law and process; constitutional conventions; egos; good and bad behaviour; all rub up against one another.

We cannot take the party politics out of public management - and we should not try. 


\section{ACKNOWLEDGEMENT}

We would like to thank John Alford and Mark Moore for critical comments that helped to sharpen our argument. We would also like to thank Gerry Stoker and the journal's three referees for their advice. The remaining defects are our responsibility.

\section{REFERENCES}

Alford, J. 2007. 'The Limits to Traditional Public Administration, or Rescuing Public Value from Misrepresentation, Australian Journal of Public Administration, 67, 3, 357-66.

Allison, G. 1983. ‘Public and Private Management: Are They Fundamentally Alike In All Unimportant Respects?', in J. Perry and K. Kraemer (eds), Public Management: Public and Private Perspectives. Palo Alto, CA: Mayfield, pp. 72-92.

ANZSOG. 2004. Cave Creek: A National Tragedy. Wellington: ANZSOG Case Program.

Armstrong, Sir R. 1985. The Duties and Responsibilities of Civil Servants in Relation to Ministers. Note by the Head of the Civil Service. London: Cabinet Office, 25 February.

Benington, J. and M. Moore (eds). 2010. In Search of Public Value: Beyond Private Choice. Basingstoke: Palgrave Macmillan.

BSE Inquiry (Phillips Inquiry). 2000. Report. Volume 1: Findings and Conclusions. London: The Stationery Office.

Bovens, M. 1998. The Quest for Responsibility: Accountability and Citizenship in Complex Organizations. Cambridge: Cambridge University Press.

Butler, Sir R. 1992. 'Managing the New Public Services: Towards a New Framework?' Public Policy and Administration, 7, 3, 1-14. Chapman, R.A. 1988. Ethics in the British Civil Service. London: Routledge.

Committee of Public Accounts. 1997. The Former Yorkshire Regional Health Authority. The Inquiry Commissioned by the NHS Chief Executive. HC 432 Session 1996-97. London: The Stationery Office.

Davis, P. and K. West. 2008. 'What Do Public Values Mean for Public Action? Putting Public Values in their Plural Place', American Review of Public Administration, doi: 0275074008328499v1.

Diesing, P. 1962. Reason in Society. Urbana, IL: University of Illinois Press.

Gains, F. and G. Stoker. 2009. 'Delivering Public Value: The Nested Possibilities in Parliamentary Democracies', Parliamentary Affairs, 62, 3, forthcoming.

Gamble, A. 1990. 'Theories of British Politics', Political Studies, 38, 3, 404-20.

Goodsell, C.T. 1985. The Case for Bureaucracy, 2nd edn. Chatham, NJ: Chatham House.

Gregory, R.J. 1998. 'Political Responsibility for Bureaucratic Incompetence: Tragedy at Cave Creek', Public Administration, 76, 3, 518-38.

House of Commons. 2004. Report of the Inquiry into the Circumstances Surrounding the Death of Dr David Kelly C.M.G. by Lord Hutton. HC 247. London: The Stationery Office, 28 January (http://www.the-hutton-inquiry.org.uk/) and (http://en.wikipedia.org/wiki/David_Kelly).

Kelly, G., G. Mulgan and S. Muers. 2002. Creating Public Value: An Analytical Framework for Public Service Reform. London: UK Cabinet Office.

Lindblom, C.E. 1990. Democracy and Market System. New York: Norwegian University Press.

Marr, D. and M. Wilkinson. 2003. Dark Victory. Sydney: Allen \& Unwin.

Marsh, D., D. Richards and M.J. Smith. 2001. Changing Patterns of Governance in the United Kingdom. Basingstoke: Palgrave.

Moore, M. 1994. 'Public Value as the Focus of Strategy', Australian Journal of Public Administration, 53, 3, 296-303.

Moore, M. 1995. Creating Public Value: Strategic Management in Government. Boston, MA: Harvard University Press.

Moore. M. 2007. 'Recognising Public Value: The Challenge of Measuring Performance In Government', in J. Wanna (ed.), A Passion for Policy. Canberra: ANU E Press, ANZSOG Monograph Series, pp. 91-116.

Noble, The Hon. G.S. 1995. Commission of Inquiry into the Collapse of the Viewing Platform at Cave Creek, Punakaiki, West Coast. Wellington: The Department of Internal Affairs.

Olsen, J.P. 2005. 'Maybe It's Time to Rediscover Bureaucracy', Journal of Public Administration Theory and Research, 16, 1, 1-24.

Packer, R. 2006. The Politics of BSE. Basingstoke: Palgrave Macmillan.

Parris, H. 1969. Constitutional Bureaucracy: The Development of British Central Administration since the Eghteenth Century. London: Allen \& Unwin.

Parliament of Australia. 2002. Senate Select Committee on a Certain Maritime Incident. Canberra: Commonwealth of Australia.

Peters, G. 1996. The Future of Governing: Four Emerging Models. Lawrence, KS: University Press of Kansas.

Plowden, W. 1994. Ministers and Mandarins. London: Institute for Public Policy Research.

Rainey, H.G. and Y.H. Chun. 2005. 'Public and Private Management Compared', in E. Ferlie, L.E. Lynn and C. Pollitt (eds), The Oxford Handbook of Public Management. Oxford: Oxford University Press, pp. 72-102.

Ranson, S. and J. Stewart. 1989. 'Management in the Public Domain', Political Studies, 37, 1, 5-24. 
Rhodes, R.A.W. 2007. 'The Everyday Life of a Minister: A Confessional and Impressionist Tale', in R.A.W. Rhodes, Paul 't Hart and M. Noordegraaf (eds), The Ethnography of Government Elites: Up Close and Personal. Basingstoke: Palgrave Macmillan, pp. 21-50.

Rhodes, R.A.W. and J. Wanna. 2007. 'The Limits to Public Value, or Rescuing Responsible Government from the Platonic Guardians', Australian Journal of Public Administration, 66, 4, 406-21.

Rhodes, R.A.W. and P. Weller (eds). 2001. The Changing World of Top Officials: Mandarins or Valets? Buckingham: Open University Press.

Rhodes, R.A.W., J. Wanna and P. Weller. 2008. ‘Reinventing Westminster. How Public Executives Reframe their World', Policy and Politics, 36, 4, 461-79.

RIPA (Royal Institute of Public Administration). 1987. Top Jobs in Whitehall: Appointments and Promotions in the Senior Civil Service. London: RIPA.

Rogers, S. (ed.). 2004. The Hutton Inquiry and its Impact. London: Politico's/Guardian Books.

Schattschnider, E.E. 1960. The Semi-sovereign People. New York: Holt Rinehart \& Winston.

Schubert, G. 1960. The Public Interest: A Critique of the Theory of a Political Concept. Glencoe, IL: The Free Press.

Shergold, P. 2008. 'Valedictory Lecture', Canberra Hyatt Hotel, 8 February (http://www.apsc.gov.au/media/shergold080208. htm).

Stoker, G. 2006. 'Public Value Management: A New Narrative for Networked Governance?', American Review of Public Administration, 36, 1, 41-57.

Strøm, K., W.C. Müller and T. Bergman. 2003. Delegation and Accountability in Parliamentary Democracies. Oxford: Oxford University Press.

The BSE Inquiry Report (Phillips Report). 2000. Volume 1: Findings and Conclusions London: The Stationery Office (http://www.bseinquiry.gov.uk/report/index.htm).

Wamsley, G.L., C.T. Goodsell, J.A. Rohr, et al. 1990. 'Public Administration and the Governance Process: Shifting the Political Dialogue', in G.L. Wamsley and J.F. Wolf (eds), Refounding Democratic Public Administration: Modern Paradoxes, Postmodern Challenges. London: Sage, pp. 31-51.

Wildavsky, A. 1968. 'The Political Economy of Efficiency: Cost-benefit Analysis, Systems Analysis and Program Budgeting', in F.J. Lyden and E.G. Miller (eds), Planning Programming Budgeting: A Systems Approach to Management. Chicago, IL: Markham, pp. 371-402.

Wildavsky, A. 1979. The Art and Craft of Policy Analysis. London: Macmillan.

Wintringham, M. 2008. Address to IPAA National Roundtable, 'Striking the Balance: Public Service Independence and Responsiveness', University of Melbourne 14 March.

Date received 9 March 2007. Date accepted 23 April 2008. 